\title{
Kondisi Karang Batu di Perairan Pulau Mantihage Kabupaten Minahasa Utara, Propinsi Sulawesi Utara
}

\author{
Status of Coral Reef at Mantihage Island Waters, North Minahasa District, North Sulawesi \\ Province
}

\section{Jemmy Souhoka}

UPT. Loka Konservasi Biota Laut LIPI Bitung

Jln. Tandurusa No.1 Bitung, Sulawesi Utara

E-mail:koral_js@yahoo.com

\begin{abstract}
Coral reefs are one of the coastal aquatic ecosystems in most of Indonesian coasts. The existence of this ecosystem is very important for organism living in or associated with it. Hard coral is one of the main components of this forming ecosystem. Coral reef research was conducted in Mantihage Island, North Sulawesi at 5 stations in September 2010 using the line transect method. The purpose of this study is to determine the condition of hard coral in Mantihage Island. The result analysis showed that the highest percentage of hard coral at station 2 is $\mathbf{7 1 . 5 7 \%}$ and the lowest at station 4 is $27.90 \%$. The highest diversity index $(H)$ of 1.07 was discovered at station 2 and the lowest 0.69 at station 5 . The highest distribution index of species (j) of 0.72 was found at station 4 dan lowest 0.44 at station 5 . A total of 97 species of coral belongs to 15 families was found at the study area. In general the condition of hard coral at the Mantihage Island is $\mathbf{4 5 . 7 8 \%}$ which includes in the middle category.
\end{abstract}

Keywords: Condition, hard coral, Mantihage Islands, North Sulawesi

\begin{abstract}
Abstrak
Terumbu karang merupakan salah satu ekosistem perairan pesisir yang dijumpai hampir di seluruh perairan pantai Indonesia. Keberadaan ekosistem ini sangat penting bagi kehidupan organisme yang ada didalamnya maupun yang berasosiasi dengannya. Karang batu merupakan salah satu komponen utama pembentuk ekosistem ini. Penelitian terumbu karang telah dilakukan di Pulau Mantihage Propinsi Sulawesi Utara pada 5 stasiun pengamatan di bulan September 2010 menggunakan metode transek garis. Tujuan penelitian ini mengetahui kondisi karang batu di perairan Pulau Mantihage. Hasil analisis menunjukkan bahwa persentase karang batu tertinggi di jumpai di stasiun 2 sebesar 71,57\% dan terendah di stasiun 4 sebesar $27,90 \%$. Nilai keanekaragaman jenis $(H)$ tertinggi 1,07 dijumpai di stasiun 2 dan terendah 0,69 di stasiun 5. Kemerataan jenis (j) tertinggi 0,72 ditemukan di stasiun 4 dan terendah 0,44 yang ditemukan di stasiun 5. Sebanyak 97 jenis karang batu milik 15 suku ditemukan di area penelitian. Secara umum rata-rata persentase karang batu di perairan Pulau Mantihage sebesar $\mathbf{4 5 , 7 8} \%$ yang berarti masuk dalam kategori sedang.
\end{abstract}

Kata kunci: Kondisi, karang batu, Pulau Mantihage, Sulawesi Utara 